\title{
VALIDATION OF MINIATURISED TENSILE TESTING ON DMLS TI6AL4V (ELI) SPECIMENS
}

\author{
I. van Zy ${ }^{1 \#}$, M. Moletsane ${ }^{1}$, P. Krakhmalev ${ }^{2}$, I. Yadroitsava ${ }^{1 *} \&$ I. Yadroitsev ${ }^{1}$
}

\section{ARTICLE INFO}

\section{Article details}

Presented at the $17^{\text {th }}$ annual

international conference of the Rapid Product Development Association of

South Africa (RAPDASA), held from 2-4

November 2016 in Vanderbijlpark, South Africa

Available online

11 Nov 2016

\section{Contact details \\ Corresponding author \\ iyadroitsava@cut.ac.za}

\section{Author affiliations}

1 Department of Mechanical and Mechatronic Engineering, Central University of Technology, Bloemfontein, Free State, South Africa

2 Department of Engineering and Physics, Karlstad University, Sweden

\# The author was enrolled for an $M$ Tech degree in the Department of Department of Mechanical and Mechatronic Engineering, University of Central University of Technology, Free State, South Africa.

DOI

http://dx.doi.org/10.7166/27-3-1666
ABSTRACT

Direct metal laser sintering (DMLS) is a relatively new technology that is developing rapidly. Since DMLS material is created by melting/solidifying tracks and layers from powder, even building geometry can influence the mechanical properties. To certify a material, the testing specimens must be designed and manufactured according to the appropriate standards. Miniaturised tensile DMLS samples could be a good alternative for express quality control, and could reduce the cost of DMLS-specific testing. In this study, as-built and stress-relieved miniaturised tensile DMLS Ti6Al4V (ELI) specimens with different surface qualities were investigated. The fracture surfaces and mechanical properties of the mini-tensile specimens were analysed and compared with standard full-sized specimens also manufactured by DMLS. The obtained data showed the applicability of mini-tensile tests for the express analysis of DMLS objects if a correction factor is applied for the calculation of the load-bearing cross-section of the specimen.

\section{OPSOMMING}

Direkte lasermetaalsintering is 'n nuwe vervaardigingstegniek wat vinnig ontwikkel. Aangesien onderdele met die tegniek vervaardig word deur poeier te smelt en dan weer te laat stol is dit belangrik dat die bougeometrie eweredig is, om sodoende die verlangde meganiese eienskappe te bewerkstellig. Om 'n materiaal te sertifiseer moet toetsmonsters ontwerp en vervaardig word volgens toepaslike standaarde. Miniature trekmonsters wat met direkte lasermetaalsintering vervaardig is, kan 'n goeie alternatief wees om gehaltebeheer te versnel. Hierdie studie gebruik onbehandelde- en spanningsverligte Ti6Al4V monsters met verskillende oppervlakafwerkings. Die kraakoppervlakke en meganiese eienskappe van die miniatuurtoetsmonsters is geanaliseer en vergelyk met standaard, volgrootte monsters ook met direkte lasermetaalsintering vervaardig. Die data toon dat die toepassing van miniatuur trektoetse vir versnelde analise van direkte lasermetaalsintering voorwerpe geldig is wanneer 'n korreksie faktor toegepas word op die lasdraende deursnee-oppervlak van die monster.

\section{INTRODUCTION}

Direct metal laser sintering (DMLS) is a powder bed fusion process used to make metal parts directly from metal powders. It is an automated process that provides a platform for the production of complex three-dimensional geometries. Three-dimensional scans or CAD data are sliced into multiple layers via software. Using this data, the machine parameters are calculated and/or chosen for the building process. First a thin layer of powder is deposited onto the building platform, after which it is scanned by the electronically-controlled laser, and the exposed area is melted by the laser beam, matching the contour area of the sliced 2D data. The next layer is deposited and exposed, which fuses with the previous sintered area and, in so doing, a 3D part is built up.

During DMLS, a very small molten pool is formed that results in a large thermal gradient at high scan speeds. The microstructure and mechanical properties obtained in DMLS are unique, and are 
influenced by different process parameters. Machine-based input parameters are also crucial to the stability of the building process, such as the laser type and its mode and spot size, protective atmosphere and its flows, delivering system, and even the substrate surface prior to exposure [1].

As-built DMLS samples can have anisotropy in mechanical properties, since DMLS is a layer-by-layer powder technology. Along with the defects inherent to non-optimal process parameters, there is a second important aspect that strongly influences the quality of the SLM material: internal stresses resulting from rapid solidification during the process. The mechanical properties of DMLS material depend on the specimen geometry, build orientation, and surface finish [2]. The DMLS surfaces are very rough, especially those that are not parallel to the building platform where powder attaches with sintered material.

Titanium alloys have two main benefits for biomedical applications: good corrosion resistance, and a high strength-to-weight ratio. Medical implants made of titanium alloys are strong, lightweight, corrosion-resistant, long-lasting, and non-ferromagnetic; and they accommodate the possibility of osseointegration. The development of biocompatible materials and new processes, such as DMLS, have resulted in significant progress in customised design and a reduction in the production time of implants and prostheses, without compromising functionality.

The capacity of DMLS to manufacture medical devices with complex shapes, in combination with the unique properties of titanium alloys, holds great promise for the medical industry. Ti6Al4V components, produced by DMLS, have to comply with international standards for biomedical applications. Different process parameters, the orientation of the object, and its design features can influence the mechanical properties (Table 1). It is therefore of paramount importance that designers know the mechanical properties of every part produced in order to ensure a safe and appropriate application. Ti6Al4V, being a heat-treatable alloy, makes it attractive for the DMLS application because post-processing can produce a variety of different properties for specific applications [3-5]. Due to very fine martensitic a' microstructure with the texture in the build direction, the DMLS object should also be heat-treated differently from wrought alloy parts.

Table 1: Mechanical properties of Ti6Al4V vertical samples produced by DMLS

\begin{tabular}{|l|l|c|c|c|c|}
\hline & $\begin{array}{c}\text { Specimen } \\
\text { labels }\end{array}$ & $\begin{array}{c}Y S, \\
\mathrm{MPa}\end{array}$ & $\begin{array}{c}\text { Young's } \\
\text { modulus, } \\
\mathbf{G P a}\end{array}$ & $\begin{array}{c}\text { UTS, } \\
\mathbf{M P a}\end{array}$ & $\begin{array}{c}\text { Elongation, } \\
\%\end{array}$ \\
\hline$[2]$ & As-built & $1070 \pm 50$ & $110 \pm 10$ & $1200 \pm 50$ & $11 \pm 2$ \\
\cline { 2 - 6 } & Annealed & $1000 \pm 20$ & $114 \pm 10$ & $1060 \pm 20$ & $15 \pm 1$ \\
\hline$[3]$ & As-built & $1143 \pm 30$ & & $1219 \pm 20$ & $4.89 \pm 0.6$ \\
\hline$[6]$ & As-built & $962 \pm 47$ & $102 \pm 7$ & $1166 \pm 25$ & $1.7 \pm 0.3$ \\
\hline$[7]$ & As-built & $664-802$ & $99-121.6$ & $1040-$ & $11.3-12.7$ \\
\hline $\begin{array}{l}\text { Standard specification for Ti6Al4V } \\
\text { alloy castings for surgical implants }- \\
\text { ASTM F1108-14 }\end{array}$ & & Min 758 & & Min 860 & Min 8 \\
\hline
\end{tabular}

\subsection{Tensile mechanical tests}

\subsubsection{Standard tensile specimens}

Tension tests provide information about certain material properties of test specimens: ultimate tensile strength (UTS), the yield stress (YS), and elongation. With the use of an extensometer, it can also provide the Young's modulus and strain rate of the material being tested. For manufacturing, uniaxial tensile stresses can be used in alloy development, quality control, and design under certain circumstances. Standard Test Methods for Tension Testing of Metallic Materials E8/E8M [8] describes the tension testing of metallic materials at room temperature; specifically, the methods of determination of YTS, UTS, elongation, and reduction of area. As indicated, ASTM E8 specimens smaller than $6 \mathrm{~mm}$ diameter can be used when tested material is too small or "when all parties agree to their use for acceptance testing" [8].

\subsubsection{Mini-specimens}

The grips used were wedge-type grips in the case of the miniature samples. This can result in small inconsistencies in the stress measurement, although it has a more significant effect on the YS and an even greater effect on the Young's modulus [9]; as a result, the data provided UTS and elongation, as these remain relatively unaffected. 
Roughness, notches, or any impurities in the samples can affect the results. Kashaev et al. [10] have shown that micro-fatigue specimens have a fatigue life similar to that of standard specimens if the cross-sections of the mini-specimens are corrected for roughness.

The aim of the present study is to determine the possibility of using as-built and polished miniaturised samples for defining the basic properties of DMLS Ti6Al4V (ELI) alloy before and after stress relieving.

\section{MATERIALS AND METHODS}

The Ti6Al4V (ELI) powder used was pre-alloyed gas atomised powder. The chemical composition was as follows: $\mathrm{Ti}$ - balance, $\mathrm{Al}-6.34 \%, \mathrm{~V}-3.94 \%, \mathrm{O}-0.058 \%, \mathrm{~N}-0.006 \%, \mathrm{H}-0.001 \%, \mathrm{Fe}-0.25 \%, \mathrm{C}-$ $0.006 \%$, and $\mathrm{Y}$ and $\mathrm{Zn}$ less than $0.001 \%$ (weight \%). The equivalent diameters (weighted by volume) of the powder particles were $d_{10}=13 \mu \mathrm{m}, d_{50}=23 \mu \mathrm{m}$, and $d_{90}=37 \mu \mathrm{m}$.

Ti6Al4V samples were produced by the EOSINT M280 system (EOS GmbH). A back-and-forth scanning by strips ( $5 \mathrm{~mm}$ width) with the hatch distance of $100 \mu \mathrm{m}$ was applied to manufacturing specimens with $30 \mu \mathrm{m}$ layer thickness. The substrate and powder materials were similar in chemical composition. Argon was used as the protective atmosphere; the oxygen level in the chamber was 0.05-0.09 per cent.

Ten vertical standard round samples with threaded ends were machined from SLM rectangular bars with dimensions of $11 \mathrm{~mm} \times 11 \mathrm{~mm} \times 62 \mathrm{~mm}$ according to the recommendations of ASTM E8, with a gauge length four to five times the diameter; the specimen's diameter was $4.3-4.5 \mathrm{~mm}$. Surface roughness for the standard round machined samples was $4.8 \pm 0.63 \mu \mathrm{m}(\mathrm{Rz})$, and Ra was $0.8 \pm 0.13 \mu \mathrm{m}$. Five bars were subjected to a stress-relieving procedure (Figure 1a). Tensile tests were performed with an Instron 1342 servo-hydraulic testing machine with circular locked grips and a clip-on extensometer of $12.5 \mathrm{~mm}$ under a constant strain rate of $1.5 \mathrm{~mm} / \mathrm{min}$.

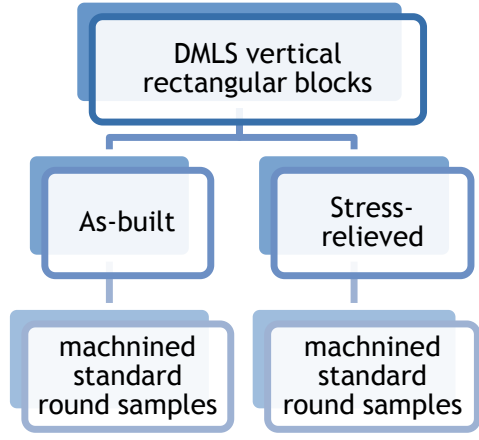

(a)

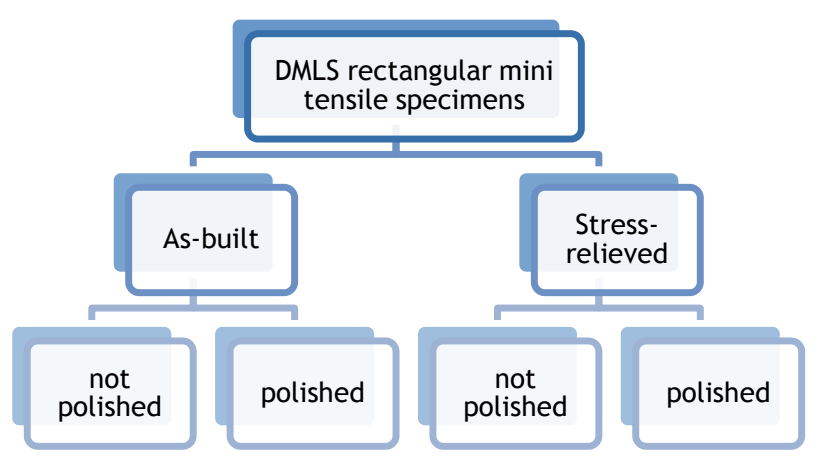

(b)

Figure 1: Design of the experiment

Sixteen rectangular pin-loaded mini-samples of $10 \mathrm{~mm}$ gauge length, $2 \mathrm{~mm}$ width, and $1 \mathrm{~mm}$ thickness were built directly at the same process-parameters by the EOSINT M280 system (Figure $2 \mathrm{~b})$. The dimensions of the tensile mini-samples are shown in Figures $2 \mathrm{a}$ and $2 \mathrm{~b}$. Tensile tests were performed with an MTS Criterion Model 43 electric testing machine with wedge grips and without extensometer under a constant strain rate of $0.25 \mathrm{~mm} / \mathrm{min}$. Clamping of the miniature samples for the purpose of tensile testing was done via customised inserts, as seen in Figures 3a-e.

Heat treatment for stress-relieving of all specimens was done in an Argon atmosphere at $650^{\circ} \mathrm{C}$ for 3 hours. 


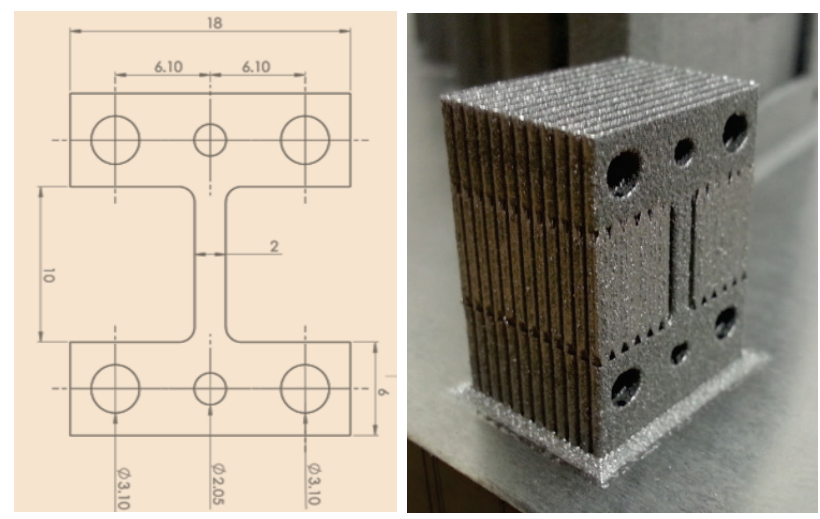

Figure 2: Dimensions sketch of mini-specimens (a) and as-built mini-specimens (b)

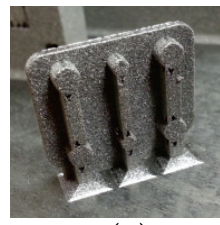

(a)

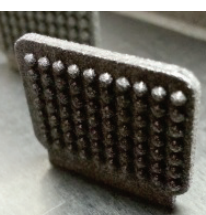

(b)

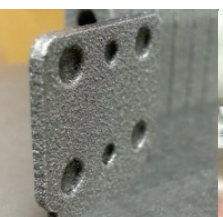

(c)

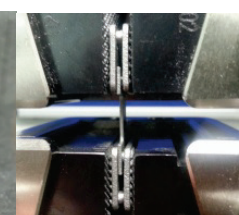

(d)

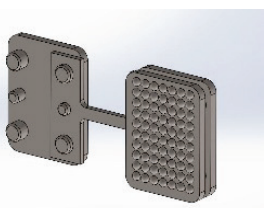

(e)

Figure 3: Insert with pins (a); grip surface (b); insert with cavity (c); mini-specimen setup with inserts and wedge grips tightened (d); and computer model of specimen and inserts (e)

The mechanical properties of standard samples manufactured vertically show excellent mechanical properties (Table 2). For standard round specimens, the Young's modulus was defined as a chord between $200 \mathrm{MPa}$ and $800 \mathrm{MPa}$, and tensile stress at Yield was defined at offset 0.2 per cent of the Young's modulus. As was indicated by Frey et al. [2], round machined samples give relatively consistent and reliable data for DMLS specimens.

Table 2: Tensile properties of Ti6Al4V ELI of as-built DMLS parts at EOS-prescribed process parameters

\begin{tabular}{|l|l|l|l|l|l|}
\hline \multicolumn{2}{|c|}{ Specimen labels } & $Y S, M P a$ & $\begin{array}{c}\text { Young's } \\
\text { modulus, } \\
G P a\end{array}$ & $\begin{array}{c}\text { UTS, } \\
M P a\end{array}$ & $\begin{array}{c}\text { Elongation, } \\
\%\end{array}$ \\
\hline $\begin{array}{l}\text { Standard round } \\
\text { specimens }\end{array}$ & As-built & $1105 \pm 9.1$ & $109 \pm 1.5$ & $1238 \pm 8.9$ & $10.74 \pm 0.7$ \\
\cline { 2 - 6 } & Stress-relieved & $1098 \pm 8.1$ & $115.8 \pm 1$ & $1171.6 \pm 6$ & $11.89 \pm 1$ \\
\hline
\end{tabular}

The analysis of the fracture surfaces of standard machined vertical samples showed that a cup-andcone shape of the necking region was observed in the as-built and stress-relieved samples. The region of fibrous fracture was in the central area of the neck (Figure 4a). The fibrous zone was irregular, with dimple rupture fracture; quasi-cleavage facets were also visible with SEM (Figure 4b). The mechanism of ductile fracture and the formation of a cup-and-cone shape in the necking region are usually associated with pore coalescence.

According to the building strategy, all the specimens were built vertically, which meant that the columnar primary $\beta$ grains also grew nearly parallel to the building direction [11]. With respect to the specimen geometry and test arrangement, the columnar primary beta grains were oriented parallel to the load application direction. Under these conditions, a crack formed due to pore coalescence propagates perpendicular to the columnar primary $\beta$ grains. In Figure $4 \mathrm{~b}$ it is seen that when the crack reaches primary $\beta$ grain boundaries or pores, the growth direction is changed. Therefore, the interface acts as a crack deflector that prevents quick failure. This conclusion is in agreement with the results presented by Wen et al. [12]. 


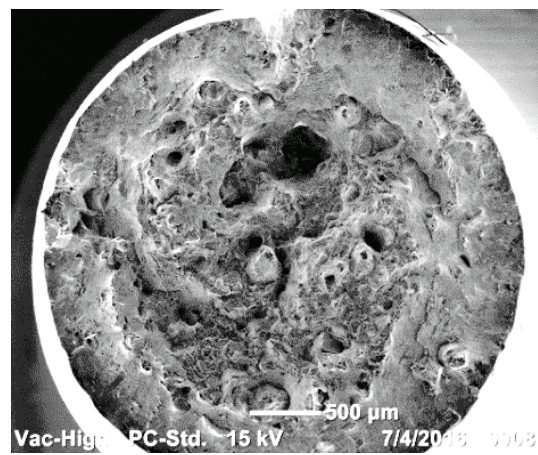

(a)

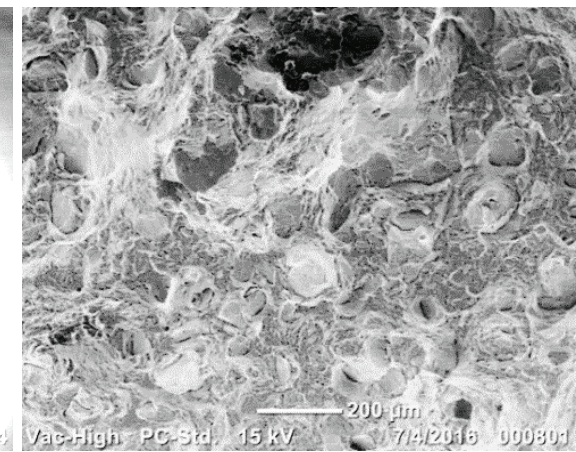

(b)

Figure 4: Fracture surface of standard vertical samples: (a) cup-and-cone shape; and fracture surface at higher magnification (b)

An examination of the tensile fracture surfaces and a comparison of the polished cross-sections of the mini-specimens by SEM revealed the specific role of macro- and micro-structure caused by the nature of the layer-by-layer DMLS. For the mini-samples, primary $\beta$ grains were oriented along the building direction (Figure 5) and had a smaller size than in the standard samples produced from bars. Representative fractographs of the tensile fracture surfaces for the mini-samples are shown in Figure 6 . On the whole, the rectangular mini-samples showed surface fractures similar to those in the standard specimens. The finer scale topography of the fracture surface and shallower dimples were observed in the fibre zones in comparison with the standard samples (Figures 4 and $6 \mathrm{c} \& 6 \mathrm{~d}$ ). A clearly observed quasi-cleavage fracture mode indicates a brittle component of fracture. Unlike in the standard specimens, a columnar microstructure is not obvious at the fracture surface. It could be associated with the finer microstructure of the mini-specimens. An estimation of the column width done by an intercept method showed that the standard specimen columns had $120 \mu \mathrm{m}$ average width, while in the mini-specimens this value was about $100 \mu \mathrm{m}$.

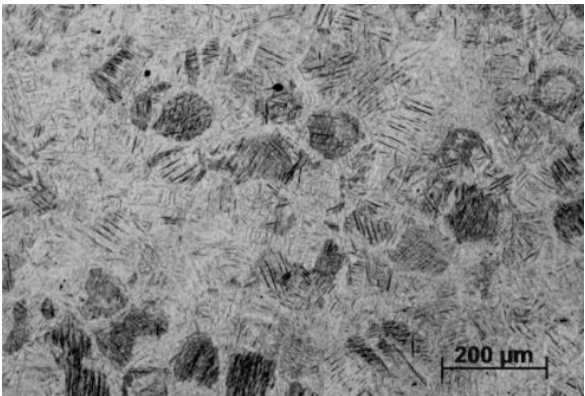

(a)

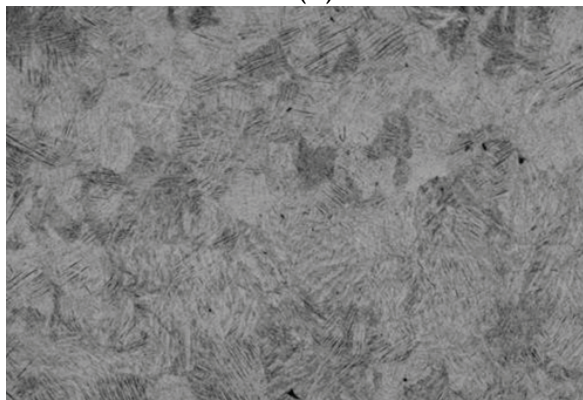

(c)

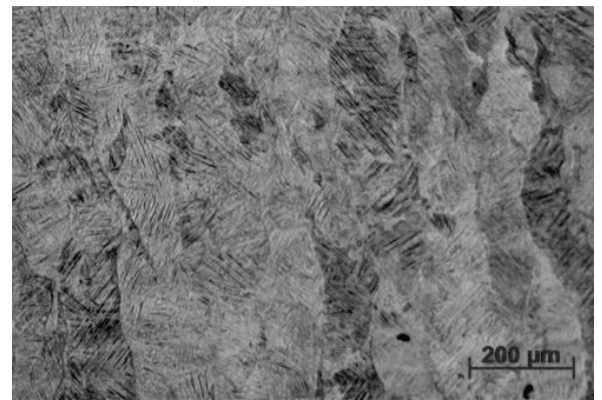

(b)

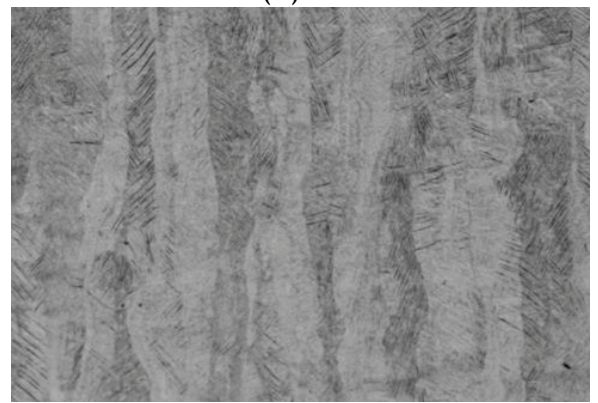

(d)

Figure 5: Cross-section of the stress-relieved standard $(a, b)$ and mini-samples $(c, d)$ perpendicular to the building direction $(a, c)$ and along the building direction $(b, d)$ 


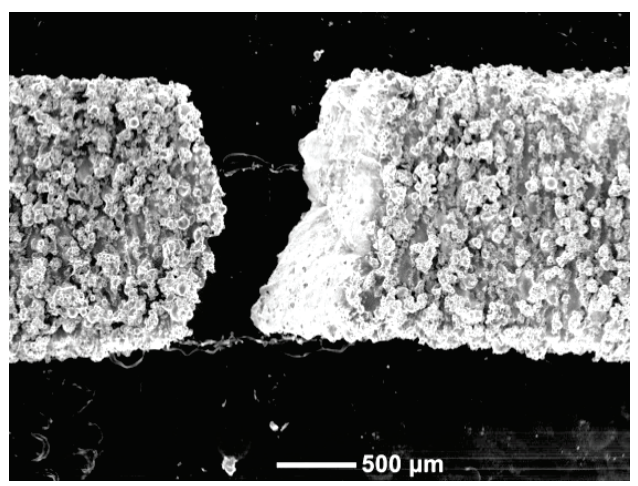

(a)

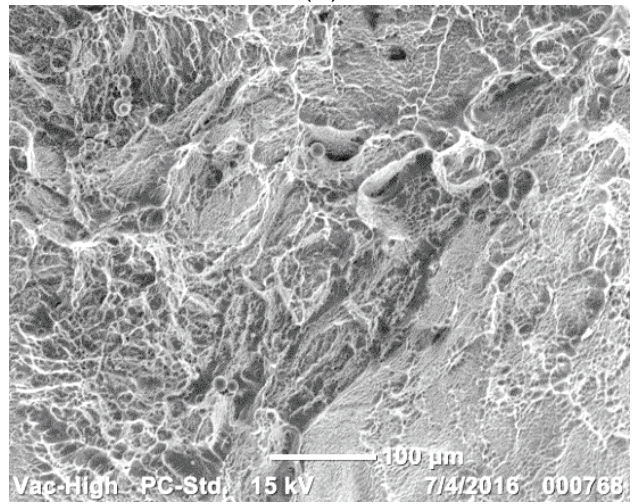

(c)

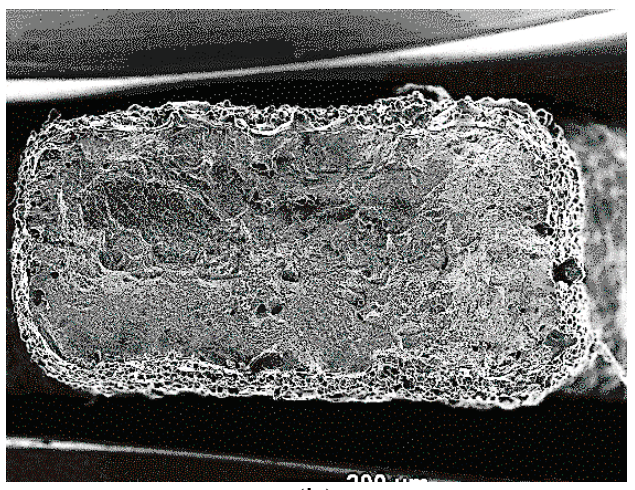

(b)

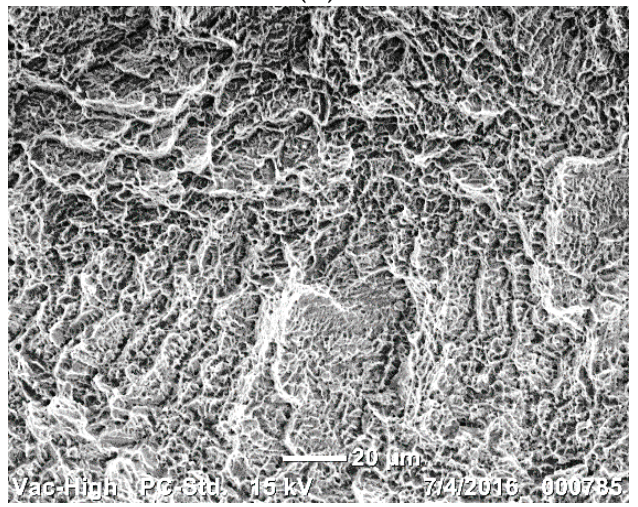

(d)

Figure 6: Fracture of as-built mini-samples $(a, c)$ and after stress-relieving heat treatment (b, d)

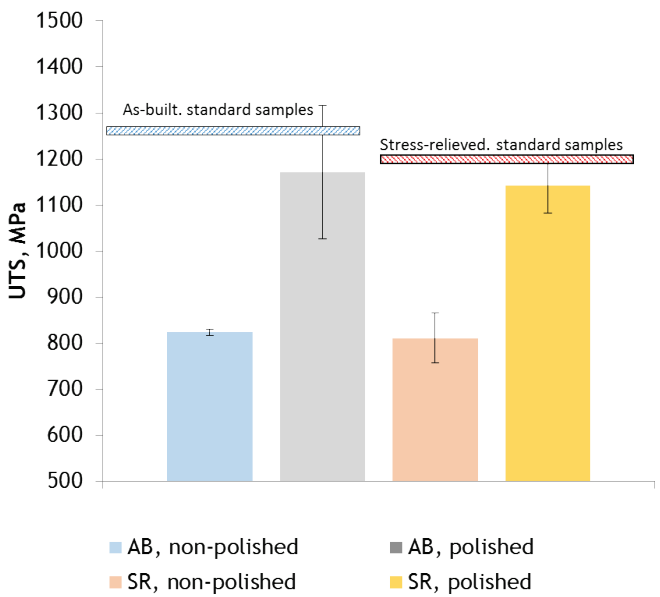

(a)

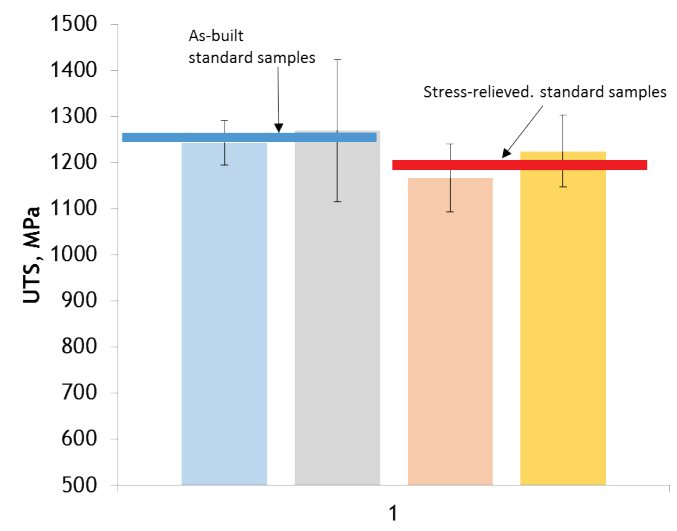

$\square \mathrm{AB}$, non-polished corrected $\square \mathrm{AB}$, polished corrected $\square \mathrm{SR}$, non-polished corrected $₫ \mathrm{SR}$, polished corrected

(b)

Figure 7: UTS for standard and mini-samples without application of the effective load-bearing cross-section (a) and corrected UTS (b)

To investigate the influence of surface finish on the tensile properties of the mini-samples, both asbuilt and stress-relieved specimens were tested, with non-polished and polished surfaces. The minisamples after polishing showed lower values for UTS than did the standard samples (Figure 7a). The UTS for the non-polished as-built specimens was 50 per cent lower than in the standard specimens. After stress-relieving, the UTS of the un-polished specimens was 45 per cent lower. After polishing, UTS increased (Table 3), but was still six per cent and three per cent lower (for the as-built and the stress-relieved specimens respectively) than for the standard samples. 
For the mini-samples, high roughness could be a crucial factor in the load-bearing cross-section. Attached partially-melted powder particles were found at the surfaces of the non-polished samples, and formed an irregular surface layer. The thickness of this layer was about $100 \mu \mathrm{m}$, and could be estimated in terms of the surface roughness characteristics as having a mean roughness depth $R_{\mathrm{z}}$. As was shown by Kashaev et al. [10], it is possible to introduce a correction factor to estimate an effective load-bearing cross-section, $A_{\text {eff }}$, :

$$
A_{\text {eff }}=\left(\mathrm{S}-2 R_{z}\right) \cdot\left(\mathrm{W}-2 R_{z}\right)
$$

where $S$ is the thickness and $W$ is the width of the mini-specimen.

Table 3: Tensile properties of Ti6Al4V ELI of as-built DMLS parts at EOS-prescribed process parameters

\begin{tabular}{|c|c|c|c|c|c|}
\hline \multirow{2}{*}{\multicolumn{2}{|c|}{ Specimen labels }} & \multicolumn{2}{|c|}{ Roughness } & \multirow{3}{*}{$\begin{array}{r}\text { UTS, } \\
\text { MPa } \\
1238 \pm 9\end{array}$} & \multirow{2}{*}{$\begin{array}{c}\text { Elongation, } \\
\%\end{array}$} \\
\hline & & $R a, \mu m$ & $R z, \mu m$ & & \\
\hline \multirow{2}{*}{$\begin{array}{l}\text { Standard round } \\
\text { specimens }\end{array}$} & As-built & \multirow[t]{2}{*}{$0.76 \pm 0.13$} & \multirow[t]{2}{*}{$4.8 \pm 0.6$} & & $10.74 \pm 0.7$ \\
\hline & Stress-relieved & & & $1172 \pm 6$ & $11.89 \pm 1$ \\
\hline \multirow{4}{*}{$\begin{array}{l}\text { Non-polished mini- } \\
\text { samples }\end{array}$} & As-built & \multirow[t]{2}{*}{$21.7 \pm 4.37$} & \multirow[t]{2}{*}{$125.2+20.49$} & $823 \pm 8$ & \multirow[t]{2}{*}{$6.6 \pm 0.4$} \\
\hline & $\begin{array}{l}\text { Cross-section } \\
\text { corrected }\end{array}$ & & & $1243 \pm 49$ & \\
\hline & Stress-relieved & \multirow[t]{2}{*}{$18.3 \pm 3.79$} & \multirow[t]{2}{*}{$109.2 \pm 24.1$} & $811 \pm 54$ & \multirow[t]{2}{*}{$6.4 \pm 1.4$} \\
\hline & $\begin{array}{l}\text { Cross-section } \\
\text { corrected }\end{array}$ & & & $1167 \pm 74$ & \\
\hline \multirow{4}{*}{ Polished mini-samples } & As-built & \multirow[t]{2}{*}{$3.5 \pm 1.11$} & \multirow[t]{2}{*}{$21.9 \pm 7.16$} & $1172 \pm 144$ & \multirow[t]{2}{*}{$6 \pm 0.9$} \\
\hline & $\begin{array}{l}\text { Cross-section } \\
\text { corrected }\end{array}$ & & & $1270 \pm 154$ & \\
\hline & Stress-relieved & \multirow[t]{2}{*}{$3.3 \pm 0.91$} & \multirow[t]{2}{*}{$19.2 \pm 7.75$} & $1143 \pm 60$ & \multirow[t]{2}{*}{$5.5 \pm 0.4$} \\
\hline & $\begin{array}{l}\text { Cross-section } \\
\text { corrected }\end{array}$ & & & $1230 \pm 78$ & \\
\hline
\end{tabular}

Applying the effective load-bearing cross-section to the experimental data obtained for the minispecimens showed results closer to UTS values received for the standard round samples (Table 3 ). It is also seen that this approach is effective for the polished specimens, as some residual surface roughness remains after polishing (Figure 8 ). Differences between the obtained elongations at breakpoint for the standard and mini-samples are attributed to the shape of the samples and size effects, and are not related to surface quality. It is seen that ductility characteristics are about the same for the polished and the non-polished specimens.

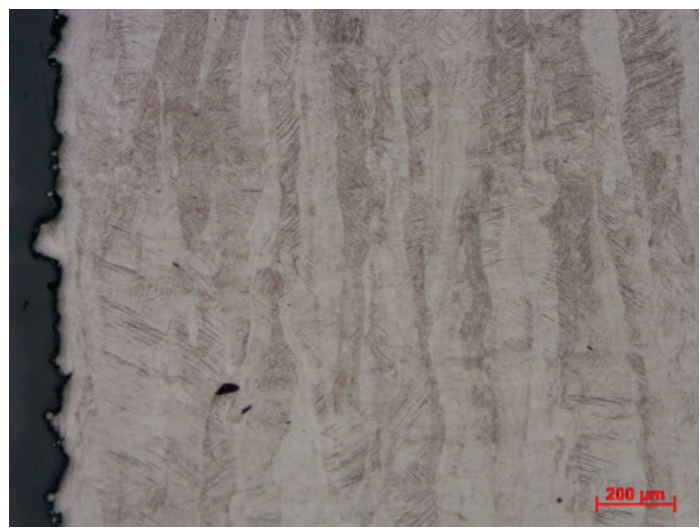

(a)

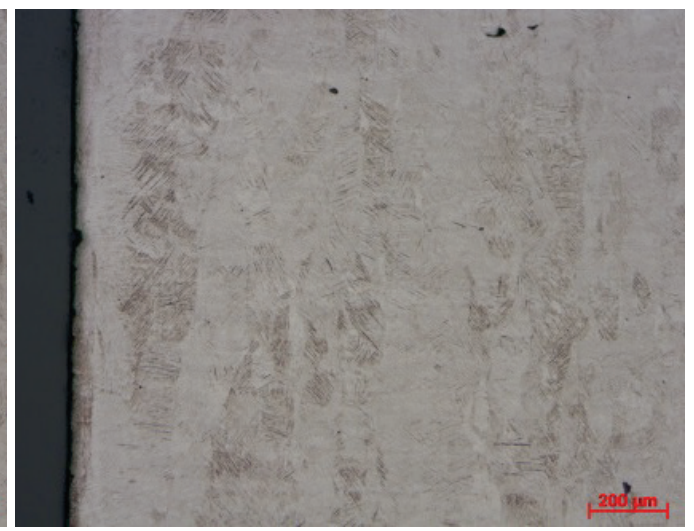

(b)

Figure 8: Cross-section of mini-samples (a) before and (b) after polishing along building direction

Besides surface roughness, a microstructural factor could also influence mechanical testing results. It has been shown by Antonysamy et al. [13] that the microstructure of Ti6Al4V in the regions near side surfaces differs from the regular bulk regions. In regions close to the side surface, the primary beta phase does not form regular vertical grains. Instead, some deviations from the vertical crystallisation direction have been observed. This could be related to a change of solidification conditions and the direction of the thermal gradient. In the present investigation, this effect was not observed. Probably due to other manufacturing parameters, primary $\beta$ also formed almost 
vertical columnar structures in regions very close to the irregular side surfaces; in the near-surface region, however, the grains are finer.

Figure 8 shows that surface polishing did not remove the material deeply enough to eliminate the influences of the side microstructure. Nevertheless, according to the experimentally-obtained mechanical properties, the differences in microstructure observed in this region apparently have a negligible influence on the mechanical properties of the mini-samples. To confirm this, a comparative analysis of mini-specimens with and without obvious differences in microstructure in the side surface region is necessary.

\section{CONCLUSIONS}

The tests done show that, even on a small scale (with a width of about 10 single tracks), the construction of DMLS components is strong and reliable. This testifies to the sound process parameters.

The mini-samples are effective for the determination of the basic properties of DMLS material. The samples were found to be relatively consistent with all the failures occurring within the gauge length. Nevertheless, due to the attached partially-melted powder layer on the side surfaces of the vertically-built samples, a correction of data is required.

Surface polishing was not found to be sufficient for improving the reliability of the measured mechanical data (deviation from standard $15-20 \%$ ) due to possible residual surface roughness. The results corrected with respect to the effective load-bearing cross-section $A_{\text {eff }}$ were found to be closest to the values obtained with reference standard tensile specimens (deviation from standard 5-7 per cent).

Further microstructural analysis has to be done to investigate the effect of the orientation of primary $\beta$ grains and texture in the mini-samples from Ti6Al4V. This data will be helpful for micromanufacturing by DMLS.

\section{ACKNOWLEDGEMENTS}

This work is based on research supported by the South African Research Chairs Initiative of the Department of Science and Technology and the National Research Foundation of South Africa (Grant №97994) and the Collaborative Programme in Additive Manufacturing (Contract №CSIR-NLCCPAM-15-MOA-CUT-01). The authors express their gratitude to Chris McDuling at the CSIR for mechanical testing and technical input.

\section{REFERENCES}

[1] Yadroitsev, I. 2009. Selective laser melting: Direct manufacturing of 3D-objects by selective laser melting of metal powders. Saarbrucken: LAP Lambert Academic Publishing AG \& Co. KG.

[2] Frey, M., Shellabear, M. and Thorsson, L. 2009. Mechanical testing of DMLS parts. EOS whitepaper, EOS GmbH Electro Optical Systems, Munich.

[3] Rafi, H., Karthik, N.V., Gong, H., Starr, T.L. and Stucker, B.E. 2013. Microstructures and mechanical properties of Ti6Al4V parts fabricated by selective laser melting and electron beam melting. Journal of Materials Engineering and Performance, 22, pp. 3873-3883.

[4] Vrancken, B., Thijs, L., Kruth, J.P. and Van Humbeeck, J. 2012. Heat treatment of Ti6Al4V produced by selective laser melting. Journal of Alloys and Compounds, 541, pp. 177-185.

[5] Yadroitsev, I., Krakhmalev, P. and Yadroitsava, I. 2014 Selective laser melting of Ti6Al4V alloy for biomedical applications: Temperature monitoring and microstructural evolution. Journal of Alloys and Compounds, 583, pp. 404-409.

[6] Vilaro, T., Colin, C. and Bartout, J.D. 2011. As-fabricated and heat-treated microstructures of the Ti-6Al$4 \mathrm{~V}$ alloy processed by selective laser melting. Metallurgical and Materials Transactions A, 42, pp. 31903199.

[7] Kasperovich, G. and Hausmann, J. 2015. Improvement of fatigue resistance and ductility of TiAl6V4 processed by selective laser melting. Journal of Materials Processing Technology, 220, pp. 202-214.

[8] ASTM E8 / E8M-16a, 2016, Standard Test Methods for Tension Testing of Metallic Materials, ASTM International, West Conshohocken, PA, www.astm.org

[9] Jia, N. and Kagan, V.A. 1999. Interpretations of tensile properties of polyamide 6 and PET based thermoplastics using ASTM and ISO procedures. In: Peraro, J.S. (ed.) Limitations of test methods for plastics, ASTM STP 1369. West Conshohocken, PA: American Society for Testing and Materials. 
[10] Kashaev, N., Horstmann, M., Ventzke, V. and Riekehr, S.H.N. 2013. Comparative study of mechanical properties using standard and micro-specimens of base materials Inconel 625, Inconel 718 and Ti-6Al-4V. Journal of Materials Research and Technology, 2(1), pp. 43-47.

[11] Simonelli, M. 2014. Microstructure evolution and mechanical properties of selective laser melted Ti-6Al$4 \mathrm{~V}$. PhD thesis, Loughborough University, UK.

[12] Wen, S., Li, S., Wei, Q., Yan, C., Zhang, S. and Shi, Y. 2014. Effect of molten pool boundaries on the mechanical properties of selective laser melting parts. Journal of Materials Processing Technology, 214, pp. 2660-2667.

[13] Antonysamy, A.A., Meyer, J. and Prangnell, P.B. 2013. Effect of build geometry on the grain structure and texture in additve manufacture of Ti6Al4V by selective electron beam melting. Materials Characterization, 84, pp. 153-168. 